\title{
Megemlékezés
}

\section{FEHÉR MÁRTA}

(1942-2020)

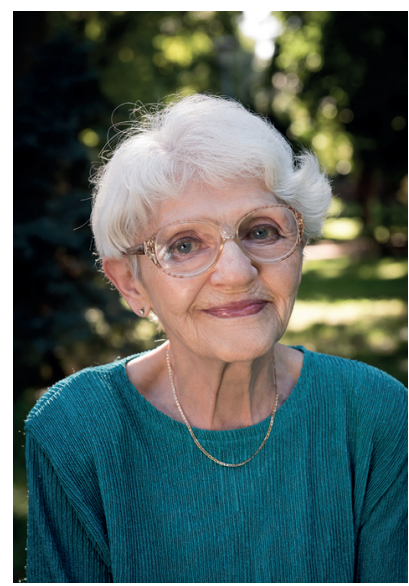

(Fotó: Hámori Zsófia)

2020 decemberében elhunyt Fehér Márta, a magyar tudománytörténet és tudományfilozófia iskolateremtő kutatója.

Az Eötvös Loránd Tudományegyetem Természettudományi Kar matematika-fizika szakán végzett 1965-ben, majd az Eötvös Loránd Tudományegyetem Bölcsészettudományi Kar filozófia szakán 1968-ban kapott előadói diplomát. Kandidátusi fokozatot 1980ban szerzett A tudományos elméletek inkommenzurábilitásának problémája címü értékezésével, MTA doktori címet 1994-ben Changing Tools - Case Studies in the History of Methodology címü munkájával nyerte el. 1965-töl a Budapesti Müszaki Egyetem Filozófia Tanszékén dolgozott, a rendszerváltást követő tíz évben a tanszék vezetőjeként. Alapító tagja volt a Technika-, Mérnök- és Tudománytörténet - későbbi nevén Tudományfilozófia és Tudománytörténet - doktori iskolának, s maga is nyolc PhD-értekezésnek volt témavezetője (1998-2017/8).

Tudományos munkásságának több, egymással szorosan összefonódó és számára természetes egységet alkotó ága volt. A tudománytörténet területén vizsgálta a görög matematika és logika kialakulásának társadalmi összefüggéseit, Galilei tudományos módszereit, a newtoni világkép kibontakozásának kérdéseit, a fizika legkisebb hatás elvének történetét, valamint a szimmetriaelvek szerepét a fizika fejlődésében. Máig sokat idézik Galileiről és Newtonról szóló tanulmányait. Különböző filozófiai szempontokból elemezte Leibniz, Thomas Kuhn, Paul Feyerabend és Polányi Mihály munkáit. Maradandót alkotott a tudományfejlődés elméletek történetének feldolgozásával és ezen elméletek belső összefüggéseinek elemzésével. Nemzetközileg is jelentős mértékben járult hozzá a tudományos ismeretek tudásszociológiai megközelítésének kidolgozásához és elfogadtatásához.

Fehér Márta oktatóként is kiemelkedő volt. A mai negyvenes-ötvenes generáció az ő írásaiból ismerte meg hazánkban a tudományfilozófia és a tudománytörténet kurrens problémáit. Ő vezette be a hazai oktatásba az informális logikát, 
más néven érveléstechnikát, és több olyan tárgyat, amely a mérnöki és üzleti tudományok hallgatói számára jól hasznosítható és reflexiót fejlesztő tudást adott.

Vendégprofesszor volt a Rutgers és a St. John's Egyetemeken, rendszeres meghívott előadó a dubrovniki Inter-University Centre tudományfilozófia és tudománytörténet kurzusain és a Láthatatlan Kollégiumban is.

Igazi iskolateremtő személyiség volt: a hazai tudománytörténészek, tudományfilozófusok és érveléstechnika-kutatók nem elhanyagolható része éppen az ő hatására kötelezte el magát szakmája mellett. Akik ma visszaemlékeznek rá, mind kiemelik segítőkészségét, és azt az energiát, amit a fiatalabb generációk felemelésére fordított. Neki köszönhetően sorsok alakultak másképp. Mindamellett zavarba ejtően szerény volt. Feladatát abban látta, hogy „bakot tartott, hogy másokat felemeljen", hogy a magasabb falak mögötti titkokat is meglássák és megértsék.

Tanításával, példamutatásával, szellemi és erkölcsi erejével kitörölhetetlen nyomot hagyott az utána következő generációkban.

Forrai Gábor

tudományfilozófus, egyetemi tanár

Láng Benedek

tudománytörténész, egyetemi tanár

Margitay Tihamér

tudományfilozófus, egyetemi tanár

Tanács János

tudománytörténész, egyetemi docens

Zemplén Gábor

tudománytörténész, egyetemi tanár 